\title{
KONSTRUKSI INDEKS KESTABILAN SISTEM KEUANGAN INDONESIA
}

\author{
Anhar Fauzan Priyono \\ Arief Bustaman \\ Fakultas Ekonomi dan Bisnis Universitas Padjadjaran \\ Email: fauzan@fe.unpad.ac.id
}

\begin{abstract}
Financial system stability is necessary to ensure a sustainable economic development. It undertakes 3 major functions: (i) payment system, (ii) financial intermediation, and (iii) managing risk. Data showed that the Indonesian economy experienced a negative correction in the event of financial instability, e.g bank panic in 1992, Asian financial crisis (1997), and Sub-prime mortgage crisis (2008). Therefore, it is necessary in having a method of financial stability index measurement, which in turn can be used to predict the direction of future financial stability. This research was conducted in order to provide an option in calculating the index of financial stability of Indonesia by two methods, namely Aggregation with Variance Equal Weight with Principal Component Analysis (PCA). The results show that the trend of Indonesian financial stability index which constructed through these two techniques have similar trend with a different magnitude. PCA method was employed in making reductions on variable dimensions without losing the information on the movement of the variable's variation. There are four sectors to be included in the index. Those four sectors are banking sector, money market sector, capital market sector, and monetary sector. We found that the contribution of the financial performance of banks in Indonesia and the interest rate is the highest among other sector to the Indonesia financial stability.
\end{abstract}

Key words: Financial system stability index, Aggregation with variance equal weight, Principal Component Analysis, Forecasting.

\section{PENDAHULUAN}

iga fungsi dasar dari sistem keuangan - mediasi pembayaran, mengintermediasi penyaluran dana tabungan masyarakat ke pendanaan investasi serta mengelola risiko - memainkan peranan yang menentukan dalam memastikan berjalan dan tumbuhnya sebuah perekonomian. Hal ini mengarah pada kesimpulan logis bahwa stabilitas sistem keuangan merupakan prasyarat untuk pertumbuhan ekonomi yang berkelanjutan. Dalam catatan sejarah QE Journal | Vol.06 - No. 01 Maret 2017 - 32 
pembangunan ekonomi Indonesia, tercatat beberapa kejadian pada sistem keuangan Indonesia. Peristiwa tersebut diantaranya adalah kepanikan di sektor perbankan pada tahun 1992; krisis Asia yang berakibat pada krisis perbankan Indonesia pada tahun 1997; serta krisis keuangan di AS tahun 2008 yang berdampak pada ketidakstabilan sistem keuangan dan perekonomian Indonesia. Data menunjukkan bahwa pertumbuhan ekonomi Indonesia mengalami penurunan ketika berbagai peristiwa ketidakstabilan sistem keuangan tersebut terjadi. Mengingat korelasi erat antara stabilitas sistem keuangan dan pertumbuhan ekonomi, maka melakukan penilaian dan pemantauan kondisi sistem keuangan menjadi sangat penting bagi Indonesia.

Pemantauan atas stabilitas sistem keuangan menjadi sangat penting, mengingat telah dipisahkannya pengawasan micro dan macro prudential di Indonesia. Beberapa studi empiris telah menerapkan beberapa pendekatan perhitungan stabilitas sistem keuangan berbasiskan literatur atas dampak dari nilai tukar dan neraca pembayaran terhadap krisis perbankan. Goodhart et al (2006) memonitor krisis finansial telah dilakukan dengan memanfaatkan indikator perbankan, yaitu profitabilitas bank dan probabilita kebangkrutan bank. Van den End (2006) menyatakan bahwa diperlukan sejumlah indikator pembentuk indeks sistem stabilitas keuangan yang dapat dibandingkan dalam tingkat internasional.

Alternatif perhitungan indeks stabilitas sistem keuangan yang ada di Indonesia diperlukan setidaknya untuk proses perbandingan dan penyesuaian dengan karakter yang dimanfaatkan dalam tingkat internasional. Penelitian ini mencoba untuk mengidentifikasi beberapa indikator yang dapat dimanfaatkan untuk proses konstruksi indeks sistem stabilitas keuangan di Indonesia. Konstruksi indeks sistem stabilitas keuangan ini sangat diperlukan dalam rangka melakukan proses pengawasan arah gerak dan perilaku indikator-indikator yang membentuknya. Secara umum, indeks stabilitas sistem keuangan diharapkan dapat membantu para pengambil kebijakan dalam memonitor pergerakan indikator keuangan utama tanpa kehilangan variasi pergerakan stabilitas keuangan secara umum, yang pada akhirnya diperlukan dalam proses pengambilan keputusan.

Tujuan dari kajian ini adalah sebagai berikut: (1) Menawarkan konsep dan metodologi alternatif penghitungan Indeks Kestabilan Sistem Keuangan

QE Journal | Vol.06 - No. 01 Maret 2017 - 33 
Indonesia; (2) Melakukan uji coba penghitungan Indeks Kestabilan Sistem Keuangan Indonesia; (3) Melakukan peramalan atas besaran Indeks Kestabilan Sistem Keuangan Indonesia.

Pendekatan serta metodologi yang digunakan untuk pengembangan pengukuran stabilitas sistem keuangan telah mengalami perubahan seiring dengan evolusi perhatian pada stabilitas keuangan dari dimensi mikroprudential menjadi makro prudensial. Dengan kata lain, perhatian telah bergeser dari analisis indikator peringatan dini untuk memantau keadaan sistem perbankan (terutama risiko default individu) kepada penilaian sistem yang lebih luas dalam hal risiko pada pasar keuangan, lembaga dan infrastruktur. Baru-baru ini, fokus analisis telah lebih jauh berkembang, di antaranya adalah menganalisa dinamika perilaku, potensi adanya penumpukan kondisi tidak stabil serta mekanisme transmisi shocks.

Salah satu pendekatan yang lazim digunakan dalam literatur adalah dengan menggunakan indikator pasar keuangan yang memiliki frekuensi tinggi (harian atau mingguan). Indikator tekanan keuangan berbasis pasar telah menjadi sangat populer dikarenakan pemantauan atas data pasar dapat menangkap perilaku dan persepsi pelaku pasar atas resiko, yang memungkinkan deteksi dini terhadap sinyal negatif di pasar keuangan. Beberapa contohnya adalah the ECB composite indicator of systemic stress (Holló, Kremer, dan Lo Duca, 2012), the IMF financial stress index (Cardarelli, Elekdag, dan Lall, 2009), the financial fragility indicator yang dikembangkan oleh para ahli di FRS (Nelson dan Perli, 2007), the financial systemic stress index of the Bank of Greece (Louzis dan Vouldis, 2011), serta the system-wide financial stress index of Hungary's Magyar Nemzeti Bank (Holló, 2012).

Pendekatan lain yang dapat digunakan adalah dengan menggunakan data dengan frekuensi lebih rendah, misalkan dengan mengkombinasikan data pasar keuangan dengan data pelaporan data keuangan oleh lembaga keuangan. Pendekatan untuk pembuatan Indeks Kestabilan Keuangan seperti ini misalnya digunakan oleh Swiss National Bank (2006) dan Banque centrale du Luxembourg (Rouabah, 2007). Pada keduanya, disamping indikator dalam balance-sheet dan indikator kinerja neraca lembaga perkreditan (seperti perubahan tingkat profit, permodalan, kualitas aset dan jumlah cabang lembaga kredit), juga digunakan indikator pasar (perubahan harga saham perbankan dan imbal hasil obligasi) dan

QE Journal | Vol.06 - No. 01 Maret 2017 - 34 
indikator lainnya (data pasar antar bank dan informasi dari otoritas pengawas).

Alternatif penggunaan indikator yang juga dapat dilakukan adalah dengan mengikutsertakan data-data makroekonomi. Contoh indeks kestabilan sistem keuangan yang menggunakan data makroekonomi adalah yang dikembangkan oleh De Nederlandsche Bank, yang terdiri dari data balance-sheet, data pasar, serta beberapa variabel ekonomi makro (nilai tukar riil efektif euro dan harga-harga sektor perumahan). Fitur lain yang menjadi kelebihan pada indeks ini adalah bahwa mereka melengkapinya dengan data pada lembaga kredit serta data kinerja lembaga keuangan lainnya (perusahaan asuransi dan dana pensiun) (Van den End, 2006). Penelitian lain, Gerdrup (2003) memanfaatkan indikator-indikator perbankan dan beberapa variabel makroekonomi sebagai faktor yang mempengaruhi krisis di Norwegia.

\section{METODE PENELITIAN}

Berikut ini adalah tahapan-tahapan serta metodologi yang digunakan dalam konstruksi Indeks Kestabilan Sistem Keuangan Indonesia:

1. Identifikasi Variabel.

Indeks Stabilitas Sistem Keuangan Indonesia dalam kajian ini terbentuk dari variabel-variabel yang mewakili tiga kelompok system keuangan, yaitu blok perbankan, blok pasar uang dan blok pasar modal. Masingmasing blok akan memiliki indikator tertentu yang mewakili performa masing-masing blok, dimana berbagai indikator tersebut akan diukur dengan variabel tertentu. Pemilihan variabel didasarkan atas kajian literatur pada bagian sebelumnya serta ketersediaan data dalam frekuensi bulanan. Penulis menghadapi keterbatasan dalam pemilihan variabel dikarenakan tidak semua variabel yang seringkali digunakan dalam berbagai studi empiris sebelumnya terdapat datanya untuk kasus Indonesia. Dua isu terkait data yang kami hadapi adalah terbatasnya data yang tersedia dalam frekuensi bulanan serta series yang yang tidak seragam untuk seluruh variabel kandidat. Khusus untuk isu series yang beragam, memberikan implikasi kepada penelitian ini yaitu bahwa periode penelitian hanya dapat dilakukan antara Februari 2005 hingga April 2014. Tabel berikut memuat berbagai variabel yang kami gunakan dalam kajian ini.

QE Journal | Vol.06 - No. 01 Maret 2017 - 35 
Tabel 1. Variabel Pembentuk Indeks Stabilitas Keuangan Indonesia

\begin{tabular}{|c|c|c|}
\hline Kelompok & Indikator & Variabel \\
\hline \multirow{5}{*}{$\begin{array}{l}\text { Kinerja } \\
\text { Perbankan }\end{array}$} & Kestabilan \& Efisiensi & $\begin{array}{lll}\text { Capital Adequancy } & \text { Ratio } \\
\text { (CAR) } & & \end{array}$ \\
\hline & Profitabilitas Perbankan & Return on Asset (ROA) \\
\hline & Likuiditas Bank & Loan to Deposit Ratio (LDR) \\
\hline & Kredit & $\begin{array}{l}\text { Tingkat suku bunga kredit } \\
\text { rata-rata (LEND) }\end{array}$ \\
\hline & Resiko Sektor Perbankan & Non Performing Loan (NPL) \\
\hline \multirow{2}{*}{$\begin{array}{l}\text { Kondisi Pasar } \\
\text { Uang }\end{array}$} & Nilai tukar & $\begin{array}{l}\text { Nilai tukar Rp terhadap US } \\
\text { Dollar ER) }\end{array}$ \\
\hline & Suku bunga antar bank & JIBOR \\
\hline Kinerja Pasar & Indeks Komposit & Indeks Harga \\
\hline Modal & & Gabungan (IHSG) \\
\hline $\begin{array}{l}\text { Kinerja Sektor } \\
\text { Moneter }\end{array}$ & $\begin{array}{l}\text { Transaksi, tabungan, kredit } \\
\text { dalam perekonomian }\end{array}$ & $\begin{array}{l}\text { Pertumbuhan Jumlah Uang } \\
\text { Beredar }\end{array}$ \\
\hline
\end{tabular}

Sumber: Analisis Data Primer 2016

2. Pembobotan dan Perhitungan Indeks

Selanjutnya, proses agregasi dari komponen-komponen pembentuk indeks stabilitas sistem keuangan Indonesia tersebut akan memanfaatkan dua cara, seperti dijelaskan dalam Sinenko, Titarenko \& Arins (2013), yaitu: (a) Agregasi dengan teknik variance-equal weights; (b) Agregasi dengan memperoleh bobot yang merupakan keluaran dari teknik Principal Component Analysis (PCA)

Agregasi dengan teknik variance-equal weights melakukan standarisasi komponen-komponen individual dan mengagregasikannya dalam satu indeks yang menerapkan bobot yang sama di antara seluruh komponen individu tersebut. Secara umum, indeks stabilitas sistem keuangan Indonesia yang dapat dibentuk dengan teknik ini memiliki formula sebagai berikut:

$$
\operatorname{ISKI}_{t}=\sum_{i=1}^{k} \frac{X_{i, t}-\overline{X_{i}}}{\sigma_{i}}
$$

dimana ISFI adalah Indeks Stabilitas Sistem Keuangan Indonesia, k adalah jumlah komponen (variabel) yang membentuk ISKI, $\overline{X_{i}}$ adalah rata-rata sampel $X_{i}$, dan $\sigma_{i}$ adalah standar deviasi dari sampel variabel $X_{i}$ 
Sedangkan agregasi dengan memanfaatkan Principal Component Analysis adalah dengan melakukan proses mereduksi dimensi dari data. Teknik ini dapat menghasilkan sejumlah kecil variabel artifisial yang tidak saling berhubungan, yang merupakan kombinasi linier dari variabel-variabel asal. Pemanfaatan teknik PCA dalam proses agregasi ini seperti juga yang telah dilakukan oleh Illing \& Liu (2006).

3. Proyeksi Indeks Stabilitas Sistem Keuangan Indonesia (Holt Winters Exponential Smoothing Additive)

Metode Exponential Smoothing ini cocok untuk data runtut waktu yang memiliki trend waktu dan variasi musiman aditif. Parameter-parameter yang akan dicari dengan memanfaatkan metode ini adalah sebagai berikut:

$$
\begin{aligned}
& a(t)=\alpha\left(y_{t}-c_{t}(t-s)\right)+(1-\alpha)(a(t-1)+b(t-1)) \\
& b(t)=\beta(a(t)-a(t-1))+1-\beta b(t-1) \\
& c_{t}(t)=\gamma\left(y_{t} a(t+1)\right)-\gamma c_{t}(t-s)
\end{aligned}
$$

dimana $0<\alpha, \beta, \gamma<1$ adalah damping factors dan $s$ adalah seasonal frequency. Forecast akan dihitung dengan persamaan sebagai berikut:

$$
\hat{y}_{T+k}=a(T)+b(T) k+c_{T+k-s}
$$

dimana seasonal factors memanfaatkan estimasi s pada periode terakhir.

4. Proyeksi Indeks Stabilitas Sistem Keuangan Indonesia (Autoregressive Moving Average)

Model time series AR, MA dan ARMA berdasarkan asumsi bahwa datadata time series yang digunakan memiliki stasioneritas yang rendah (weakly stasionarity) artinya bahwa rata-rata dan varians-nya konstan sedangkan kovarians-nya tidak berubah sepanjang waktu. Dalam kenyataannya data time series banyak yang tidak stasioner tetapi bisa terintegrasi dalam I(1) first difference, I(2) second difference, dan bisa sampai $I(d)$, d-th difference sehingga data bisa stasioner, $\mathrm{I}(0)$.

Oleh karena itu sebelum melakukan proses AR dan MA terlebih dahulu harus dilakukan proses pengujian stasionaritas sehingga pada d-difference berapa suatu data bisa stasioner. $\operatorname{ARMA}(p, q)$ yang diaplikasikan pada data yang telah melalui proses differencing dinamakan model ARIMA(p,d,q), yaitu model Autoregressive Integrated Moving Average, di mana $\mathrm{p}$ ialah 
jumlah variabel autoregressive, d ialah proses differencing sehingga data menjadi stasioner, dan q ialah jumlah variabel moving average.

Di dalam membuat ARIMA terdapat tahapan yang harus dilakukan terkait dengan penentuan AR, MA, dan integrasi variabel yang tidak stasioner. Berikut ini beberapa tahapan untuk melakukan estimasi model dengan ARIMA yaitu: (1) Identifikasi model, yaitu merupakan proses menentukan tingkat stasionaritas data (d) serta menentukan nilai AR (p) dan MA (q); (2) Mengestimasi Parameter dari model yang dipilih; (3) Melakukan Diagnostic Checking ( Apakah estimasi residualnya stasioner/white noise ? ); (4) Melakukan Forecasting.

Di dalam model ARIMA ini yang paling sulit ialah menentukan model mana yang benar dan terbaik sehingga membentuk model ARIMA $(\mathrm{p}, \mathrm{d}, \mathrm{q})$ :

$$
Y_{t}=\mu+\alpha_{0} Y_{t-1}+\alpha_{1} Y_{t-2}+. .+\alpha_{2} Y_{t-p}+\beta_{0} \varepsilon_{t}+\beta_{1} \varepsilon_{t-1}+. .+\beta_{q} \varepsilon_{t-q}
$$

dengan Yt dapat stasioner pada level, first difference atau second difference.

Kriteria untuk menentukan model ARIMA yang terbaik adalah sebagai berikut: (a) Nilai AIC dan BIC yang relative kecil; (b) Nilai SEE yang relative kecil; (c) Nilai Adj $\mathrm{R}^{2}$ yang relatif tinggi; (d) Residual dari model yang dipilih bersifat white noise

Setelah diketahui model yang benar dan terbaik maka tahap selanjutnya ialah melakukan forecasting pada model ARIMA yang dibuat. Setelah diketahui model ARIMA yang tepat maka untuk melakukan forecasting dapat dilakukan sebagai berikut yaitu: (a) Tentukan sampai periode mana forecasting akan dilakukan; (b) Forecasting dengan model ARIMA di atas

\section{HASIL DAN PEMBAHASAN}

Pada bagian ini akan dijelaskan statistik deskriptif dari variabel-variabel yang digunakan dalam konstruksi indeks stabilitas sistem keuangan Indonesia. Khusus untuk tiga variabel, yaitu pertumbuhan kredit perbankan; nilai tukar serta jumlah uang berdedar, kami lakukan transformasi menjadi dalam pertumbuhan (dalam persen)

Statistik Deskriptif atas variabel-variabel pembentuk indeks stabilitas sistem keuangan di Indonesia (ISKI) adalah sebagai berikut. 
Tabel 2. Statistik Deskriptif Variabel Pembentuk ISKI Februari 2005 - Juni 2014

\begin{tabular}{lllllllllll}
\hline & CAR & GCREDIT & GER & GIHSG & JIBOR & LDR & LEND & GMS & NPL & ROA \\
\hline Mean & 18.86 & 0.71 & 0.10 & 0.59 & 8.11 & 73.17 & 13.96 & 0.52 & 4.39 & 2.94 \\
Median & 18.41 & 0.79 & 0.05 & 1.19 & 7.68 & 74.58 & 13.88 & 0.47 & 3.42 & 2.93 \\
Max & 23.02 & 2.02 & 6.65 & 7.97 & 14.52 & 91.17 & 16.64 & 3.72 & 11.05 & 3.87 \\
Min & 16.05 & -1.06 & -3.12 & -16.38 & 4.20 & 50.52 & 11.90 & -3.97 & 1.48 & 1.27 \\
Std.Dev. & 1.71 & 0.61 & 1.11 & 2.95 & 2.57 & 10.71 & 1.40 & 1.38 & 2.80 & 0.45 \\
Skewness & 0.57 & -0.66 & 1.83 & -1.81 & 0.81 & -0.34 & 0.30 & -0.14 & 0.91 & -0.09 \\
Kurtosis & 2.23 & 3.66 & 13.65 & 11.62 & 3.08 & 2.22 & 2.02 & 3.42 & 2.52 & 3.86 \\
\hline
\end{tabular}

$C A R=$ Capital Adequacy Ratio

GCREDIT $=$ Pertumbuhan Kredit Perbankan

GER $=$ Pertumbuhan Nilai Tukar Rupiah terhadap US Dollar

GIHSG = Pertumbuhan Indeks Harga Saham Gabungan

JIBOR $=3$ Month JIBOR rate

$L D R=$ Loan to Deposit Ratio

LEND = Tingkat suku bunga rata-rata kredit perbankan

GMS $=$ Pertumbuhan Jumlah Uang Beredar

$N P L=$ Non Performing Loan

ROA = Return on Asset

Konstruksi Indeks Kestabilan Sistem Keuangan Indonesia

Bagian berikut menjelaskan hasil-hasil dari perhitungan indeks tersebut dengan memanfaatkan metode Aggregation with Variance Equal Weight dengan Principal Component Analysis (PCA). Dengan menerapkan metode Aggregation with variance equal weight untuk menghitung ISK, maka didapatkan nilai-nilai sub-indeks (10 sub-indeks) sebagai berikut

QE Journal | Vol.06 - No. 01 Maret 2017 - 39 


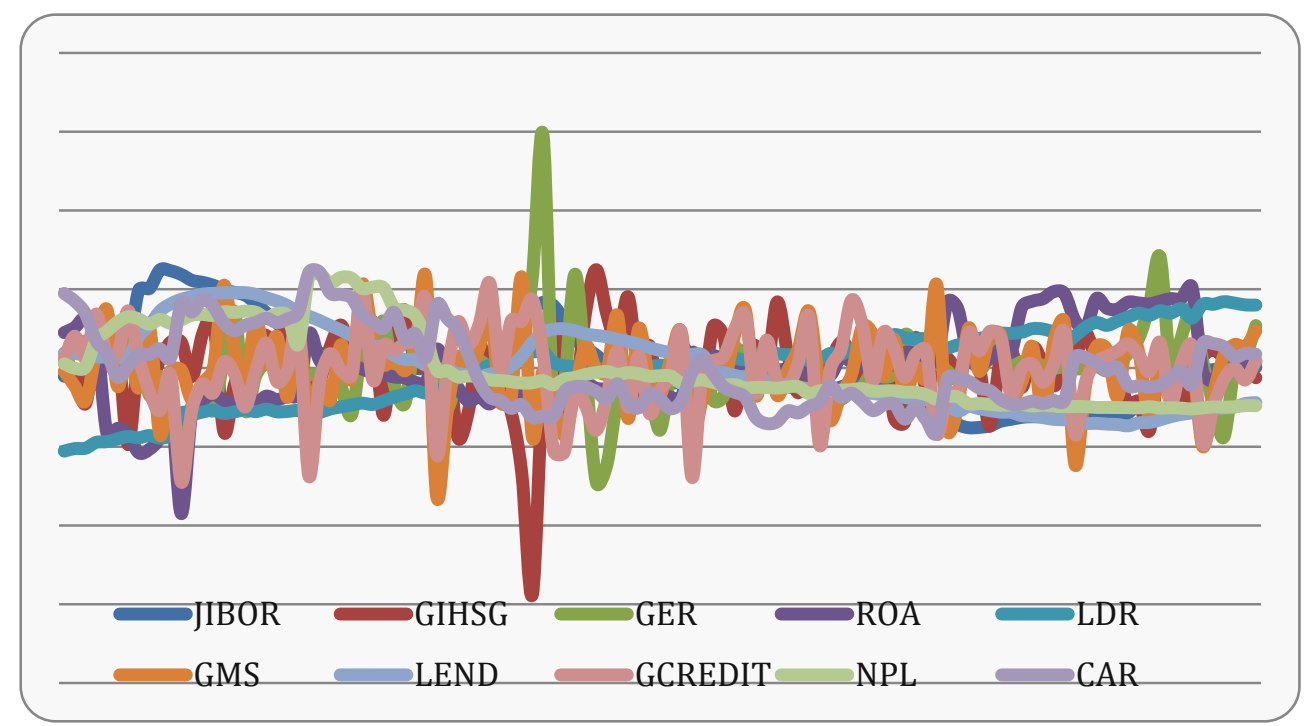

Grafik 1. Nilai Sub-indeks Pembentuk ISK Metode Aggregation with Variance Equal Weight

Sedangkan perbandingan perhitungan ISFI antara metode Aggregation with Variance Equal Weight dengan Principal Component Analysis (PCA) adalah sebagai berikut:

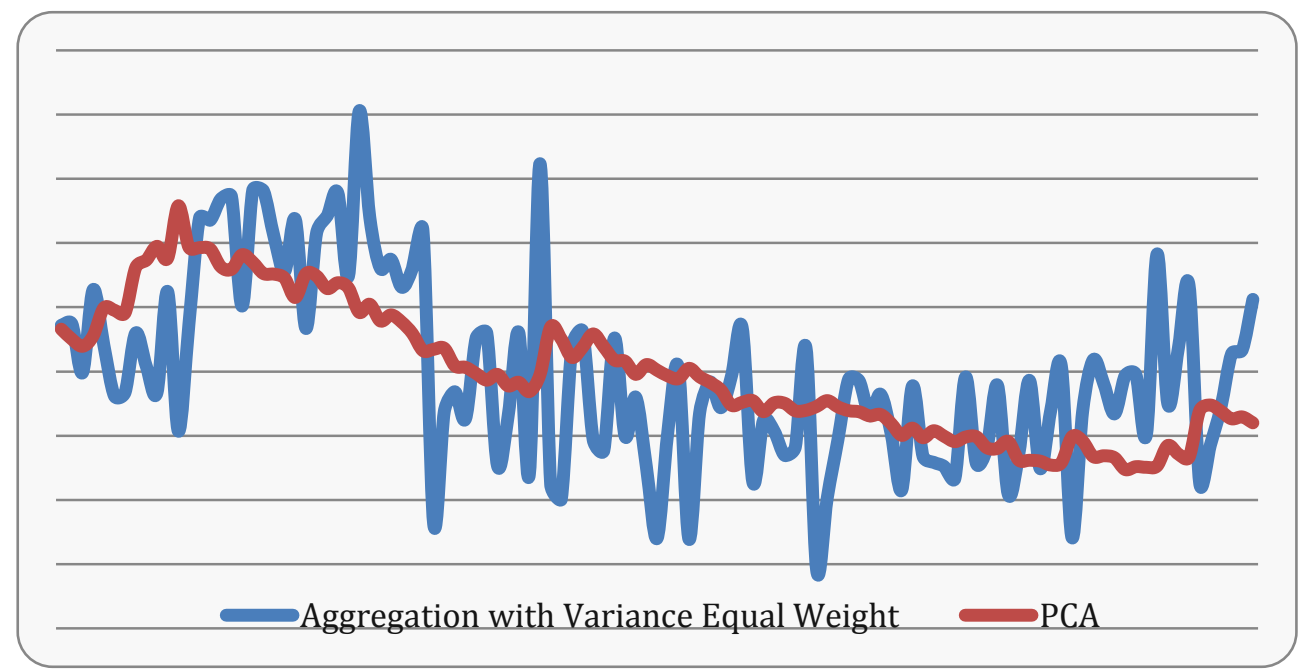

Grafik 2. Indeks Stabilitas Sistem Keuangan Indonesia (Aggregation with Variance Equal Weight \& Principal Component Analysis)

Hasil perhitungan Indeks Stabilitas Sistem Keuangan Indonesia dengan memanfaatkan teknik Aggregation with Variance Equal Weight dengan QE Journal | Vol.06 - No. 01 Maret 2017 - 40 
Principal Component Analysis (PCA) memperlihatkan kemiripan trend, walaupun dengan magnitude yang berbeda. Indeks yang terbentuk melalui teknik pertama menghasilkan angka indeks yang relatif lebih fluktuatif dibandingkan dengan metoda kedua. Hal lain yang perlu dijelaskan dalam hasil kedua metode adalah terdapat perbedaan trend indeks pada periode antara bulan Juni 2011 hingga Januari 2012. Dalam periode ini, metode PCA menunjukkan trend indeks yang menurun, sedangkan dalam teknik Aggregation with Variance Equal Weight cenderung fluktuatif. Dalam Sinenko, Titarenko \& Arins (2013), dijelaskan bahwa nilai-nilai indeks yang berada di atas rata-rata historisnya (sebesar nol), menunjukkan stabilitas finansial yang makin lemah, ditandai dengan meningkatnya stress pada komponen-komponen pembentuk indeks finansial tersebut. Di lain pihak, ketidakseimbangan dalam ekonomi sedang terbentuk apabila nilai indeks berada di bawah nilai nol secara persisten. Hal ini mengindikasikan probabilita peningkatan stress level secara signifikan pada periode selanjutnya.

Temuan awal dari analisis PCA memperlihatkan bahwa terdapat 4 komponen yang membentuk indeks stabilitas finansial Indonesia. Hal ini ditunjukkan oleh besaran akumulasi proporsi dalam menjelaskan indeks tersebut, yaitu sebesar 83,4\%, dan nilai eigenvalue yang lebih besar dari 1 . Komponen pertama (PC 1) memiliki kontribusi tertinggi yaitu sebesar $42,9 \%$.

Tabel 3 Eigenvalue

\begin{tabular}{cccccc}
\hline Number & Value & Difference & Proportion & $\begin{array}{c}\text { Cumulative } \\
\text { Value }\end{array}$ & $\begin{array}{c}\text { Cumulative } \\
\text { Proportion }\end{array}$ \\
\hline 1 & 4.290029 & 2.490828 & 0.429 & 4.290029 & 0.429 \\
2 & 1.799201 & 0.552791 & 0.1799 & 6.089229 & 0.6089 \\
3 & 1.24641 & 0.241578 & 0.1246 & 7.335639 & 0.7336 \\
4 & 1.004832 & 0.461473 & 0.1005 & 8.34047 & 0.834 \\
5 & 0.543359 & 0.130698 & 0.0543 & 8.883829 & 0.8884 \\
6 & 0.412661 & 0.131993 & 0.0413 & 9.29649 & 0.9296 \\
7 & 0.280668 & 0.070796 & 0.0281 & 9.577158 & 0.9577 \\
8 & 0.209871 & 0.073017 & 0.021 & 9.787029 & 0.9787 \\
9 & 0.136854 & 0.060738 & 0.0137 & 9.923883 & 0.9924 \\
10 & 0.076117 & 0 & 0.0076 & 10 & 1 \\
\hline
\end{tabular}

QE Journal | Vol.06 - No. 01 Maret 2017 - 41 
Berikut diatas adalah tabel eigenvalues perhitungan indeks stabilitas finansial Indonesia dengan memanfaatkan teknik PCA

Hasil eigenvalue diatas kemudian dibandingkan dengan scree plot (ordered eigenvalues) untuk memastikan jumlah komponen (PC) yang akan membentuk indeks stabilitas finansial sebagai berikut

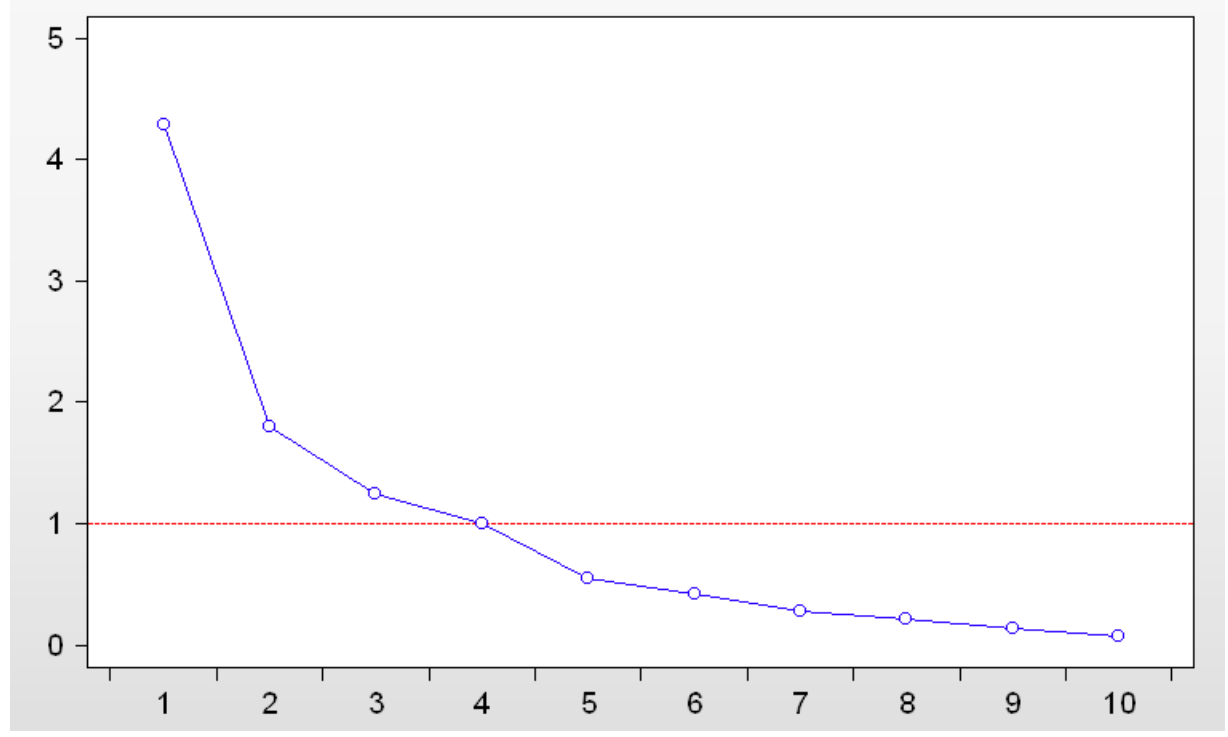

Grafik 3. Scree Plot (Ordered Eigenvalues)

Namun hasil analisis lebih lanjut menunjukkan bahwa hasil scree plot memperlihatkan loadings sudah landai pada PC 3. Sehingga dapat disimpulkan bahwa hanya 3 komponen (PC 1, PC 2, dan PC 3) saja yang membentuk indeks stabilitas finansial Indonesia.

Variabel-variabel yang masuk ke dalam komponen pertama (PC 1) dan secara bersama-sama paling besar memberikan kontribusi atas indeks stabilitas finansial Indonesia adalah sebagai berikut (koefisien korelasi dalam kurung): (1)Capital Adequacy Ratio (0,328), (2)JIBOR $(0,406)$, (3) Loan to Deposit Ratio $(-0,422)$, (4)Rata-rata Tingkat Suku Bunga Kredit Perbankan $(0,455),(5)$ Return on Asset Perbankan (-0.35)

Kelima variabel tersebut diatas dapat dikategorikan sebagai kelompok kinerja bank dan tingkat suku bunga. PC 1 tersebut memberikan kontribusi sebesar $42,9 \%$ terhadap pergerakan indeks stabilitas finansial Indonesia. PC 1 kemudian dipergunakan untuk melakukan perhitungan indeks stabilitas

QE Journal | Vol.06 - No. 01 Maret 2017 - 42 
finansial Indonesia dengan alasan kemampuan komponen tersebut adalah paling besar diantara komponen lainnya, dan, mengingat upaya teknik PCA dalam mereduksi dimensi variabel.

\section{Proyeksi Indeks Stabilitas Sistem Keuangan Indonesia}

Pada bagian ini akan dijelaskan permodelan yang bertujuan untuk mempelajari perilaku historis dari indeks stabilitas sistem keuangan Indonesia untuk kemudian dapat digunakan sebagai peramalan (forecasting) atas Indeks Stabilitas Sistem Keuangan Indonesia.

Teknik permodelan yang dipilih adalah Holt-Winters Exponential Smoothing dan Autoregressive Moving Average (ARMA). Selanjutnya dilakukan proses peramalan data indeks di luar periode estimasi, sepanjang 12 bulan, dimulai dari Juli 2014. Data indeks yang dipergunakan dalam permodelan ini adalah kedua data indeks hasil perhitungan dua pendekatan sebelumnya.

Hasil pengujian akar unit dari data indeks hasil perhitungan Aggregation with Variance Equal Weight (AVG), dan PCA menunjukkan bahwa kedua data indeks stasioner pada tingkat perubahan pertamanya (1st difference).

Hasil permodelan dengan memanfaatkan pendekatan $\operatorname{ARMA}(7,0)$ dan ARMA(1,0), berturut-turut untuk perubahan AVG dan perubahan PCA, mengikuti informasi PACF pada correlogram masing-masing, adalah sebagai berikut (t-statistik dalam kurung):

$$
\begin{gathered}
\Delta A V G_{t}=-0,003-0,167 \Delta A V G_{t-7} \\
(-0,08) \quad(-1,72)^{*}
\end{gathered}
$$

* = signifikan pada tingkat signifikansi 10\%

Root Mean Squared Error (RMSE) persamaan (7) adalah 0,395, Mean Absolute Error (MAE) adalah 0,269, dan Mean Absolute Percentage Error adalah 99,639. Sedangkan R2 adalah 0,028.

$$
\begin{gathered}
\Delta P C A_{t}=-0,027-0,158 \Delta P C A_{t-1} \\
(-0,66) \quad(-1,67)^{*}
\end{gathered}
$$

* = signifikan pada tingkat signifikansi $10 \%$

Root Mean Squared Error (RMSE) persamaan (8) adalah 0,436, Mean Absolute Error (MAE) adalah 0,297, dan Mean Absolute Percentage Error adalah 109,92. Sedangkan R2 adalah 0.025.

QE Journal | Vol.06 - No. 01 Maret 2017 - 43 
Selanjutnya, permodelan variabel indeks AVG dan PCA dengan memanfaatkan pendekatan Holt-Winters Exponential Smoothing Adaptive.

Nilai-nilai $\alpha$, $\beta$, dan $\gamma$ untuk estimasi AVG berturut-turut adalah 0,2; 0,2; dan 0,3. Sedangkan nilai-nilai $\alpha, \beta$, dan $\gamma$ untuk estimasi PCA berturutturut adalah 0,23; 0,1; dan 0,13. Besaran R2 untuk estimasi AVG dan PCA dengan pendekatan Holt-Winters Exponential Smoothing Adaptive adalah berturut-turut sebesar 0,52 dan 0,08.

Selanjutnya, Root Mean Squared Error (RMSE), Mean Absolute Error (MAE), dan Mean Absolute Percentage Error (MAPE) untuk estimasi AVG berturut-turut adalah 0,274; 0,189; dan 1,753.

Sedangkan Root Mean Squared Error (RMSE), Mean Absolute Error (MAE), dan Mean Absolute Percentage Error (MAPE) untuk estimasi PCA berturut-turut adalah 0,419; 0,279; dan 2,498.

Evaluasi perbandingan kinerja permodelan indeks yang dihitung dengan metode AVG dan PCA, yang diestimasi dengan memanfaatkan teknik permodelan ARMA dan Holt Winters Exponential Smoothing Adaptive adalah sebagai berikut:

Tabel 4. Perbandingan Kinerja Permodelan Indeks Stabilitas Finansial Indonesia (AVG) ARMA $(7,0)$ dan Holt Winters Exponential Smoothing Adaptive

\begin{tabular}{ccc}
\hline \multirow{2}{*}{ Indikator } & \multicolumn{2}{c}{ Teknik Permodelan } \\
& ARMA (7,0) & HW ES Adaptive \\
\hline $\mathrm{R}^{2}$ & 0.028 & $\mathbf{0 . 5 2}$ \\
RMSE & 0.395 & $\mathbf{0 . 2 7 4}$ \\
MAE & 0.269 & $\mathbf{0 . 1 8 9}$ \\
MAPE & 99.639 & $\mathbf{1 . 7 5 3}$ \\
\hline
\end{tabular}

Angka dicetak tebal menunjukkan nilai yang lebih baik 
Tabel 5. Perbandingan Kinerja Permodelan Indeks Stabilitas Finansial Indonesia (PCA) ARMA dan Holt Winters Exponential Smoothing Adaptive

\begin{tabular}{ccc}
\hline \multirow{2}{*}{ Indikator } & \multicolumn{2}{c}{ Teknik Permodelan } \\
& ARMA(1,0) & HW ES Adaptive \\
\hline $\mathrm{R}^{2}$ & 0.025 & $\mathbf{0 . 0 8}$ \\
RMSE & 0.436 & $\mathbf{0 . 4 1 9}$ \\
MAE & 0.297 & $\mathbf{0 . 2 7 9}$ \\
MAPE & 109.92 & $\mathbf{2 . 4 9 8}$ \\
\hline
\end{tabular}

Angka dicetak tebal menunjukkan nilai yang lebih baik

Holt Winters Exponential Smoothing Adaptive memberikan hasil estimasi atas indeks stabilitas finansial Indonesia yang dihitung dengan Aggregation with Variance Equal Weight (AVG) dan PCA, yang lebih superior dibandingkan dengan hasil estimasi dengan metode $\operatorname{ARMA}(1,0)$. Selanjutnya disajikan hasil peramalan indeks stabilitas finansial Indonesia yang dihitung dengan Aggregation with Variance Equal Weight (AVG) dan PCA untuk 12 bulan setelah Juni 2014, yang berbasiskan Holt Winters Exponential Smoothing Adaptive sebagai berikut:

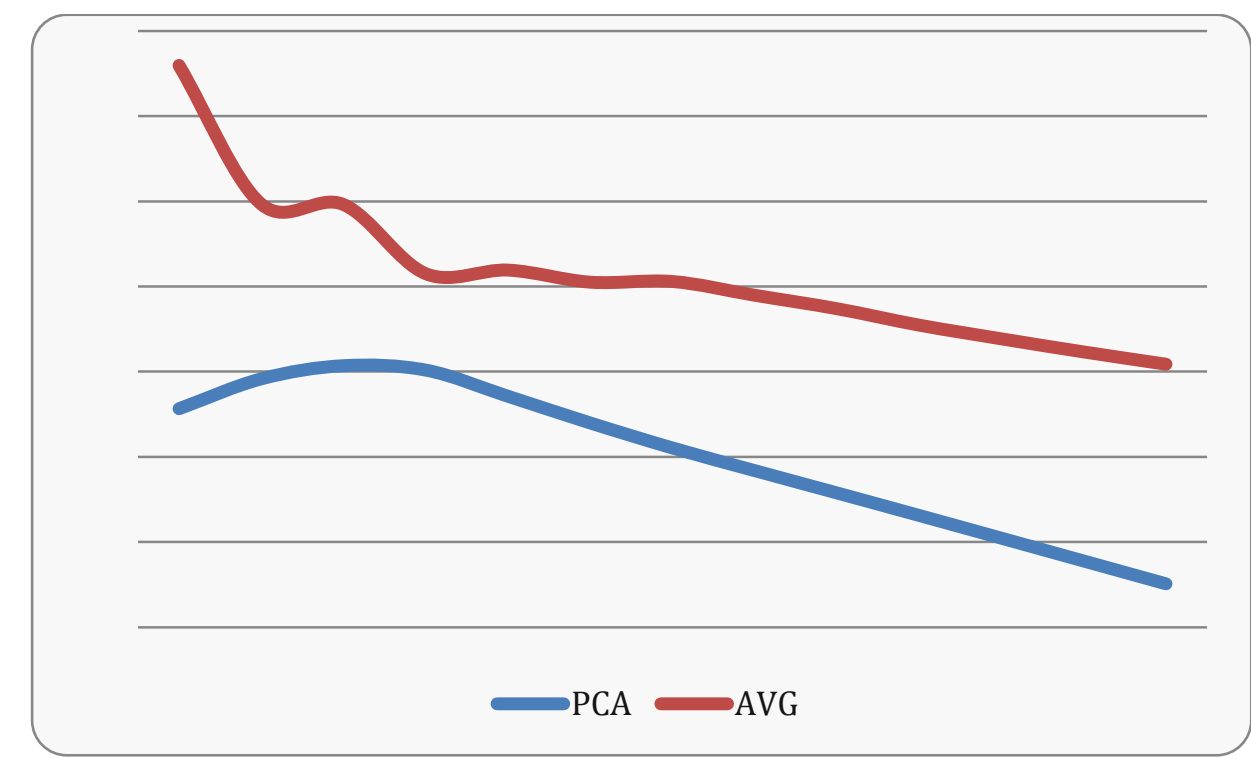

Grafik 4. Proyeksi Indeks Stabilitas Finansial Indonesia (AVG dan PCA) Juli 2014 - Juli 2015 


\section{SIMPULAN DAN SARAN}

\section{Simpulan}

Penelitian ini dilakukan dalam upaya memberikan pilihan dalam menghitung indeks stabilitas finansial Indonesia dengan 2 metode, yaitu Aggregation with Variance Equal Weight dengan Principal Component Analysis (PCA). Hasil analisis memperlihatkan bahwa trend indeks stabilitas finansial Indonesia yang dihitung melalui kedua teknik ini memiliki kemiripan trend dengan magnitude indeks yang berbeda.

Dalam analisis PCA yang dimaksudkan untuk melakukan reduksi atas dimensi variabel tanpa harus kehilangan informasi atas variasi pergerakan variabel yang dibentuk, ditemukan bahwa kontribusi kinerja keuangan perbankan di Indonesia dan tingkat suku bunga adalah variabel-variabel yang paling besar kontribusinya terhadap pergerakan stabilitas finansial Indonesia.

\section{Saran}

Selanjutnya, dalam kerangka proyeksi pergerakan indeks stabilitas finansial Indonesia, disimpulkan bahwa hasil estimasi metode Holt Winters Exponential Smoothing Adaptive lebih superior dibandingkan Autoregressive Moving Average. Trend pergerakan indeks stabilitas finansial Indonesia 12 bulan ke depan (dimulai dari Juni 2014), menunjukkan trend yang menurun, dan bergerak di dekat rata-rata jangka panjangnya, yaitu nol. Hal ini menunjukkan stabilitas finansial Indonesia diproyeksikan akan cenderung berada di luar stress level

\section{DAFTAR PUSTAKA}

Cardarelli, R., Elekdag, S., Lall, S. (2009). "Financial Stress, Downturns, and Recoveries", IMF Working Paper No. WP/09/100, May. p. 60.

Gerdrup, KR. (2003), "Three Episodes of FInancial Fragility in Norway since the 1890's", BIS Working Papers, No. 142, October.

Goodhart, C, O Aspachs, M Segoviano, D Tsomocos and L Zicchino (2006): "Searching for a metric for financial stability", LSE Financial Markets Group Special Paper Series, Special Paper no 167, May.

Grimaldi, B. M. (2010), "Detecting and Interpreting Financial Stress in the Euro Area". ECB Working Paper Series No. 1214, June, p. 66.

QE Journal | Vol.06 - No. 01 Maret 2017 - 46 
Holló, D. (2012). "A System-Wide Financial Stress Indicator for the Hungarian Financial System", Magyar Nemzeti Bank Occasional Paper No. 105, September. p. 42.

Holló, D., Kremer, M., Lo Duca, M. (2012). "CISS - A Composite Indicator of Systemic Stress in the Financial System", ECB Working Paper Series No. 1426, March. p. 51.

Illing M and Y Liu (2003): "An index of financial stress for Canada", Bank of Canada Working Paper no 2003-14, June.

Louzis, D.P., dan Vouldis, A.T. (2011). "A Financial Systemic Stress Index for Greece".

URL: http://papers.ssrn.com/sol3/papers.cfm?abstractid $=1736570$

Nelson, W.R., dan Perli, R. (2007). "Selected Indicators of Financial Stability", in Proceedings of the ECB Fourth Joint Central Bank Research Conference on Risk Measurement and Systemic Risk. April, pp. 343-372

Rouabah, A. (2007). "Mesure de la vulnérabilité du secteur bancaire Luxembourgeois", Banque centrale du Luxembourg Working Paper No. 24, April.

Sinenko, N., Titarenko, D., Arins, M. (2013), "The Latvian Financial Stress Index as an Important Element of the Financial System Stability Monitoring Framework", Baltic Journal of Economics 13(2) (2013), 85110.

Swiss National Bank (2006). Financial Stability Report. p. 60

Van den End, J W. (2006), "Indicator and Boundaries of Financial Stability". DNB Working Paper, No. 97/March. 